SCADide

Infer, Interpret \& Inspire Science
International Journal of Dentistry and Oral Science (IJDOS)

ISSN: $2377-8075$

\title{
Effect of Intrasocket Application of Ozonized Olive Oil Gel on Postsurgical Pain and Soft Tissue Healing of Impacted Mandibular Third Molars Surgery: Split-Mouth Randomized Controlled Trial
}

Research Article

Wadhah M.A. Ghanem ${ }^{1}$, Yasser Al-Moudallal' ${ }^{2}$ Mohamad Droubi ${ }^{3}$, Zuhair Al-Nerabieah ${ }^{* *}$

${ }^{1}$ Department of Oral and Maxillofacial Surgery, Faculty of Dentistry, Damascus University, Damascus, Syria.

${ }^{2}$ Professor, Department of Oral and Maxillofacial Surgery, Faculty of Dentistry, Damascus University, Damascus, Syria.

${ }^{3}$ Department of Oral and Maxillofacial Surgery, Faculty of Dentistry, Damascus University, Damascus, Syria.

${ }^{4}$ Pediatric Dentistry Department, Faculty of Dentistry, Damascus University, Syria.

Abstract

Objectives: The aim of this study has been to estimate the analgesic and soft tissue healing effect of applying ozonized oliveoil gel on the extracted site of impacted mandibular third molars postoperatively.

Material and Methods: 30 visiting patients with asymptomatic bilateral impacted mandibular third molars were enrolled in this split-mouth single-blinded randomized controlled trial. They form the current sample: $(n=60)$. Randomization was attained using the envelop method, so that each patient was assigned into the corresponding group without the previous knowledge of the researchers. Henceforth, one impacted third molar on one side was extracted and ozonized gel was applied right before suturing; this is for the study side. The control-side impacted molar was extracted 3 weeks later with a \pm 5 -day difference; no substance was applied here, only prescribed antibiotic $(1 \mathrm{~g}$ Augmentin, twice a day for 7 days). The mean age of the 30 patients was $20.7 \pm 2.3$ (ranging17-25 years). The degree of postsurgical pain was evaluated utilizing the visual analogue scale (VAS) of faces for 7 days post extraction; the number of analgesic (acetaminophen $500 \mathrm{mg}$ )tablets taken was also decided for 7 days later on. Soft tissue healing was evaluated via Landry et al and Gonshor Index on the 7th day postoperatively. Results: The study group demonstrated statistically significant reduction in the degree of pain. The intake of analgesic tablets was, on the other hand, less compared to the control group. When assessed on the 7th day after the surgery, soft tissue healing in the study group proved better than that in control group $(\mathrm{p}<0.05)$. No side effects of the ozonized olive-oil gelwere traced in any patient.

Conclusion: This studyshowed significant effect of intrasocket topical application of ozonized gel on pain and soft tissue healing as well as being a sufficient substitute to regular post-surgical antibiotics.

Keywords: Ozonized Gel; Impaction; Third Molar Surgery; Pain; Soft Tissue Healing.

\section{Introduction}

Ozone $\left(\mathrm{O}_{3}\right)$ in its gaseous form with a molecular weight of 47.98 $\mathrm{gram} / \mathrm{mol}$ is found in the stratosphere of the Earth. It is an unstable gas continually created and broken down into oxygen $\left(\mathrm{O}_{2}\right)$ under the effect of temperature and pressure $[1,2]$. Evidence from the literature of this topic exists recommending the use of ozone in medical and dental fields. This recommendation is ascribed to its unique properties on the human body, such as its powerful antimicrobial action (viricidal,bactericidal, and fungicidal). Other ad- vantages are renowned as being immune modulatory and stimulating, anti-inflammatory, biosynthetic, antihypoxic,bioenergetics, homeostatic,etc. [3-6]. For more than a decade, it has been famous for its applications in clinical fields for treatment of various diseases, like infections, burns, circulatory disorders, skin lesions and chronic non-healing ulcers [3]. One of its most common utilizations in dental practice is the surgical extractions of impacted molars. Nonetheless, the use of ozonized olive-oil gel in oral and maxillofacial surgery has been limited, as the published articles and data are found to be scarce $[7,8]$. Currently, ozone is avail-

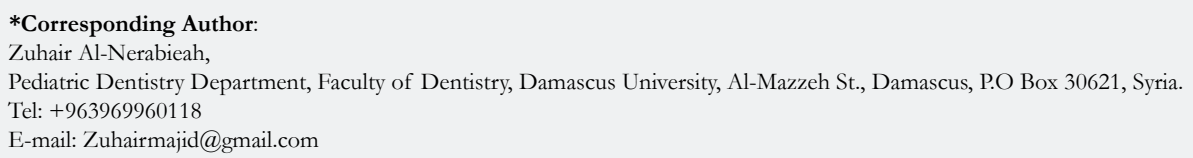

Citation: Wadhah M.A. Ghanem, Yasser Al-Moudallal, Mohamad Droubi, Zuhair Al-Nerabieah. Effect of Intrasocket Application of Ozonized Olive Oil Gel on Postsurgical Pain and Soft Tissue Healing of Impacted Mandibular Third Molars Surgery: Split-Mouth Randomized Controlled Trial. Int J Dentistry Oral Sci. 2021;8(2):1571-1577. doi: http://dx.doi. org/10.19070/2377-8075-21000312

Copyright: Zuhair Al-Nerabieah ${ }^{\circ}$ 2021. This is an open-access article distributed under the terms of the Creative Commons Attribution License, which permits unrestricted use, distribution and reproduction in any medium, provided the original author and source are credited. 
able and used in numerous forms like gaseous, aqueous, or gel [9]. The ozone gas dissolves in plant oils, such as olive oil to form ozonized olive-oil gel, it has demonstrated antimicrobial effects, facilitating wound healing in the oral cavity $[10,11]$.

The ozonized olive-oil gel was chosen to our study because of its benefits. Its application is not complicated, presence of higher concentration of ozone molecules, and stability of the compound for longer period - unlike the ozone gas. No necessity is required for a complex status to produce, manage, and store. The ozonized olive-oil gel conserves the biological characteristics of cells to an optimal level when compared with the gaseous form [12]. The ozonized gel contains ozonides which contact with wound surface at body temperature, leading to release power and active ozone in long time [13]. A plethora of its benefits in dental surgical extraction do not stop at promoting hemostasis, increasing local circulation and prolonging anti-microbial efficacy [14].

Several authors reported that the extended recovery and postsurgical complications and discomfort lead to risk indicators [7, $15,16]$, so this randomized clinical trial emphasized studying the efficacy of ozonized olive-oil gel on post-surgical pain and soft tissue healingto minimize such expected risks.

\section{Materials And Methods}

The study design assumes the model of a randomized controlled trial, conducted on 30 patients attending the clinic of Oral and Maxillofacial Department at Damascus University between December 2019 and March 2020. It is a split-mouth design: both of the study and control groups were assigned in the same patient, to avoid bias based on individual variations. The guidelines and procedures were explained; moreover, an informed written consent was provided by each patient in order to be enrolled in this study. The protocol of this study followed the accordance of the Declaration of Helsinki on medical protocols and ethics; it was approved by Research Ethics Committee at Damascus University, and was processed according to CONSORT 2010 checklist to include a randomized trial (Figure-1).

The sample selection and group allocation was prepared according to the following inclusion and exclusion criteria:

Inclusion criteria were to receive asymptomatic, symmetrical, bilateral impacted mandibular third molars with similar difficulty index as assessed by Pell \& Gregory and Winter Scale: grade IIB, having normal bleeding and clotting times.

Exclusion criteria were to reject patients with systemic disease, contraindicated for or allergic to ozone therapy, local or chronic infection, tobacco use, pregnancy and contraceptive use and lactation.

The bilateral impacted molars were distributed by a simple randomization method (envelop draw) for both the study group and the control one. The molar of one side was extracted surgically, and the other one on the side after 3 weeks ( \pm 5 days). This time delay was to ensure the disappearance of signs and symptoms of the first surgery, and the outcomes of one extraction do not influence the other. Additional simple randomization was used via envelops to decide which side to begin with. To avoid bias, the patients and statistician carrying out the measurement were blinded as on which side gel ozonized was applied and which was the control.

Our patients were instructed to avoid any antibiotics or anti-inflammatory drugs 12 hours before surgery. The control group was prescribed $1000 \mathrm{mg}$ Augmentin. Nevertheless, analgesic tablets $500 \mathrm{mg}$ acetaminophen were instructed to be taken when necessary in both groups, $0.2 \%$ chlorhexidine mouth rinse three times a day: one minute for one week, and an ice pack to the surgical area was applied for at least 30 minutes. The operative procedure was carried out under local anesthesia, performed with $2 \%$ lidocaine +1: 80,000 epinephrine solution. Modified Ward's flap was used, reaching adequate elevation and reflection of buccal mucoperiosteal flap, and necessary bone removed by slow-speed straight surgical hand piece (rotation speed $15000 \pm 2000 \mathrm{rpm}$ ). This was accompanied by continuous irrigation with physiological saline solution $(0.9 \%)$. In the study side before the sided mucoperiosteal flap was repositioned and sutured - after irrigation and debris removal - ozonized gel was applied filling the socket completely. This makes the gel more applicable and retainable. The time necessary for tooth extraction was set starting from the first incision to the last suture; any complications, e.g. altered nerve sensation, alveolar osteitis, or bleeding, were registered.

\section{Ozone therapy}

Ozonized olive-oil gel used throughout this study is produced from Triangle healing products (cjvj+f8 Victoria, British Columbia, Canada) (Figure-6). It is made by bubbling highly concentrated ozone gas produced from medical grade oxygen through pure cold pressed organically grown extra virgin olive oil. No stabilizers, color or any other additives are mixed with the product. We must use cold corona discharge ozone generator technology to ozonize the olive oil at the highest ozone setting possible.

\section{Evaluation}

Pain was assessed post operatively every seven days by patients, using the visual analogue scale (VAS) of faces according to Rathnam et al. 2010 (17) (Figure-2). The total analgesic doses taken on seven post-surgical days were also evaluated and recorded. The surgical time needed for the teeth extractions (starting from the first surgical incision to the last closure sutures of the wounds) was recorded. Patients were recalled on day 7 post-surgically to evaluate soft tissue healing based on the criteria given by Landry et al and Gonshor [18, 19]. Statistically, the mean values and standard deviations were evaluated for each parameter for the study and control groups:

Healing Index 1: Very poor (has two or more of the following)

- Tissue color: C 50\% of gingiva red

- Response to palpation: bleeding

- Granulation tissue: present

- Incision margin: not epithelialized, with loss of epithelium beyond incision margin

- Suppuration present

Healing Index 2: Poor

- Tissue color: C $50 \%$ of gingiva red 
- Response to palpation: bleeding

- Granulation tissue: present

- Incision margin: not epithelialized, with connective tissue exposed

Healing Index 3: Good

- Tissue color: C 25\% and 50\% of gingiva red

- Response to palpation: no bleeding

- Granulation tissue: none

- Incision margin: no connective tissue exposed

Healing Index 4: Very good

- Tissue color: $25 \%$ of gingiva red

- Response to palpation: no bleeding

- Granulation tissue: none

- Incision margin: no connective tissue exposed

Healing Index 5: Excellent

- Tissue color: all tissues pink

- Response to palpation: no bleeding
- Granulation tissue: none

- Incision margin: no connective tissue exposed

Statistically, the mean values and standard deviations were evaluated for each parameter for the study and control groups. Comparisons between two sides were performed using Mann-Whitney Test, except for the analgesic doses taken; these were calculated with the independent sample t-Test. SPSS version 24.0 was used to analyze our present data.

\section{Results}

Randomly, a total of 30 patients (17 males and 13 females) were enrolled and evaluated in all the stages for our study. The flowchart of the study illustrates patient enrollment and allocation, no loss of cases was experienced in all the stages of the study (Figure-1). The mean patient age bordered 20.67 years \pm 2.301 (Table 1). Sixty teeth were extracted without observing any postsurgical teeth extractions complications, for instance alveolar osteitis, paresthesia, altered nerve sensation, or bleeding. The mean surgical time (from the first incision done to the last suture) taken was $19.11 \mathrm{~min} \pm 3.027$ and $17.06 \mathrm{~min} \pm 3.171$ for the control and study groups respectively.

Figure 1. Flowchart of the study.

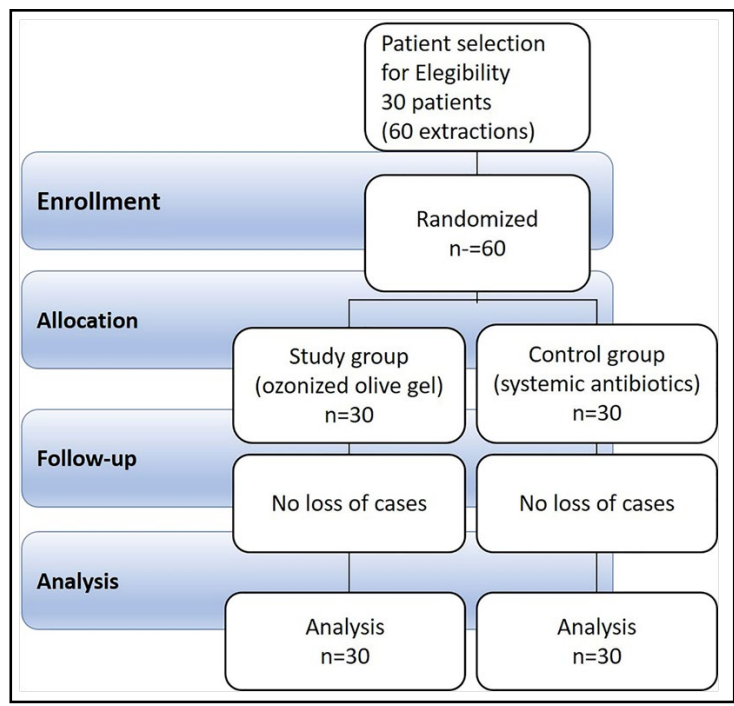

Table 1. Distribution of comparatives and variables via tests results.

\begin{tabular}{|c|c|c|c|c|}
\hline \multirow{2}{*}{ Units } & Study (ozone) group & Control group & \multirow{2}{*}{$\begin{array}{c}\text { Test } \\
\text { value }\end{array}$} & \multirow[b]{2}{*}{$\mathrm{p}$} \\
\hline & Mean \pm SD & Mean \pm SD & & \\
\hline Age (years) & $20.67 \pm 2.301$ & $20.67 \pm 2.301$ & 0 & $1.000 \mathrm{a}$ \\
\hline Surgery time (min) & $17.06 \pm 3.171$ & $19.11 \pm 3.027$ & -1.989 & $0.055 \mathrm{a}$ \\
\hline Soft tissue healing-seventh day & $4.17 \pm 0.924$ & $3.11 \pm 0.900$ & 3.07 & $0.002 \mathrm{~b}$ \\
\hline Total analgesic dose & $13.13 \pm 3.117$ & $26.19 \pm 2.588$ & -12.897 & $0.000 \mathrm{a}$ \\
\hline VAS-surgery day & $2.06 \pm 0.680$ & $3.13 \pm 0.957$ & -3.269 & $0.001 \mathrm{~b}$ \\
\hline VAS- first day & $1.81 \pm 0.655$ & $3.75 \pm 0.577$ & -4.797 & $0.000 \mathrm{~b}$ \\
\hline VAS-second day & $1.81 \pm 0.544$ & $3.38 \pm 0.619$ & -4.633 & $0.000 \mathrm{~b}$ \\
\hline VAS-third day & $2.06 \pm 0.772$ & $2.56 \pm 0.727$ & -1.745 & $0.081 \mathrm{~b}$ \\
\hline VAS-fourth day & $1.63 \pm 0.619$ & $2.25 \pm 0.447$ & -2.887 & $0.004 \mathrm{~b}$ \\
\hline VAS-fifth day & $1.13 \pm 0.342$ & $1.63 \pm 0.5$ & -2.875 & $0.004 \mathrm{~b}$ \\
\hline VAS-sixth day & $1.00 \pm 0.000$ & $1.25 \pm 0.447$ & -2.104 & $0.035 b$ \\
\hline VAS-seventh day & $1.06 \pm 0.250$ & $2.25 \pm 0.931$ & -3.909 & $0.000 \mathrm{~b}$ \\
\hline
\end{tabular}

a Student t-test.

b Mann-Whitney U test. 
The VAS scores of the study groups yielded statistically significant reduction in the post-operative pain scores on post-surgical days $(p<0.05$; Table 1$)$. Therewere no significant difference in VAS score at the third day post-surgical days $(\mathrm{p}<0.05 ; \mathrm{p}=0.081$ Table 1). The entire analgesic dose intake in the study side was significantly less $(p=0.000 ; p<0.005$; Table 1$)$. Pain climax for the study (ozone gel) group was detected on the surgery day and for the control group on the first post-surgical day (Figure-3). Patients were recalled on 7 th day post-surgically and evaluated for soft tissue healing scores $3.11 \pm 0.90$ and $4.17 \pm 0.92$ in the control and study side, respectively. This shows significantly higher rates (better) in study (ozone gel) group as compared with the control group ( $\mathrm{p}=0.002 ; \mathrm{p}<0.05$; Table 1$)$.

\section{Discussion}

The purpose of this split-mouth randomized controlled trial was to determine whether ozonized olive-oil gel improved patient comfort following impacted mandibular third molar surgery compared with routine post-surgical systemic antibiotics intake. It was hypothesized that the patient comfort was better with ozonized olive-oil gel application compared with the negative ozone systemic antibiotic group. The ultimate aims of this study were to evaluate and compare the post-surgical pain and soft tissue healing in both groups. The informed results of this study confirmed this hypothesis.

Figure 2. Visual analogue scale(VAS) of faces using in this study (Rathnam et al.2010).

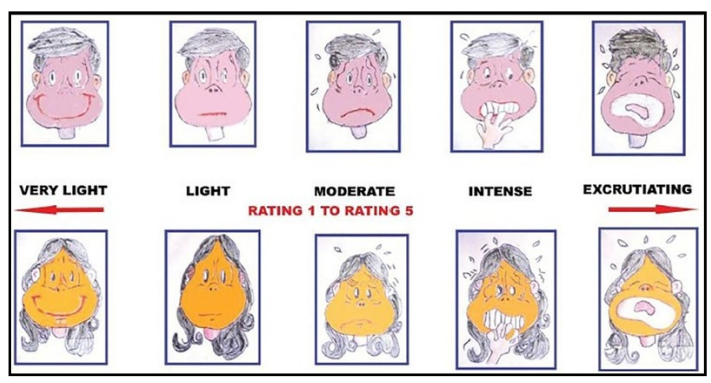

Figure 3. Histogram reveal the mean of analgesic doses using in this study.

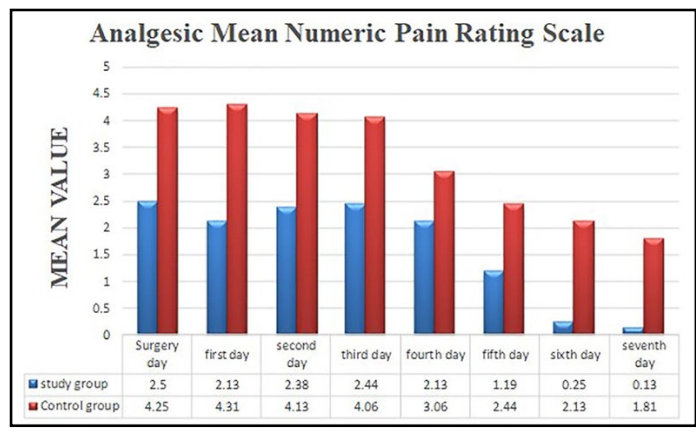

Figure 4. Histogram reveal the mean of VAS using in the study.

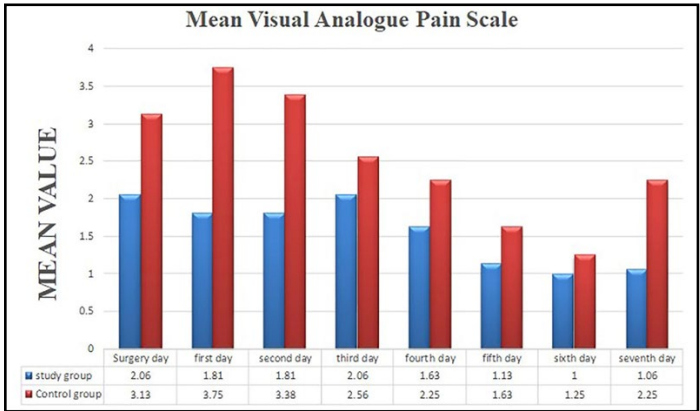

Figure 5. Histogram reveal the mean of soft tissue healing scale in 7 th day after surgery.

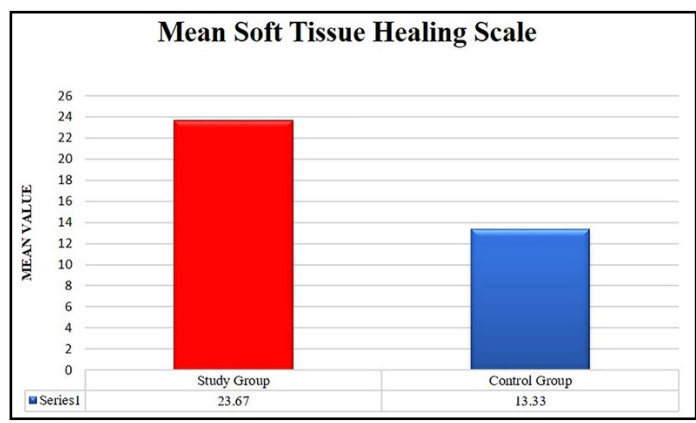


Figure 6. Ozonized olive oil gel used on this study produced from Triangle healing products (cjvj+f8 Victoria, British Columbia, Canada.

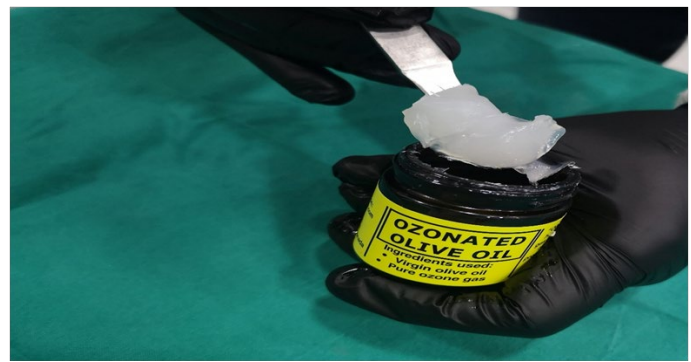

Figure 7. Test (Ozone gel) group. (a) surgery set and ozone gel. (b-d) surgical procedure. (e). intrasocket application of ozone gel. (f) post-operative suturing.

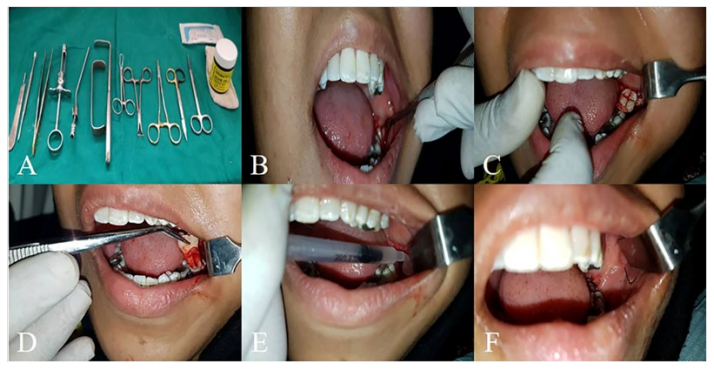

Statistically, there was significant reduction in the post-surgical pain and the need of analgesics. This was accompanied by fast and better soft tissue repair in the study ozonized gel application.

Ozone is one of the most powerful antimicrobial agents used in dental fields: bactericidal, veridical, fungicidal [4-9]. The bactericidal efficacy is through damaging and disrupting the cell membrane, disintegrating and oxidizing the intracellular contents. It eliminates $99 \%$ of microflora in a few 10-20 seconds span. In viruses under the influence of reverse transcriptase, it prevents the synthesis of viral proteins; in fungus, it alters negatively cell growth in different selective stages [9,20]. Ozone is able to kill and destroy bacteria 3500 times more effectively and faster than chlorine [21]. It has rheological properties [22], activating cellular metabolism [23], and exhibiting intercellular ATP concentration and cytokines expression [24]. This concept affects positively the healing of soft tissue injury, especially the transforming growth factor-B1 (TGF-B1) [25]. The activation of these growth factors, local antioxidant mechanisms besides the antimicrobial efficacy enhance oral soft tissue repair and reduce post-operative disturbance and pain [26].

The most abiding complications after surgical removal of the third molar are pain, swelling, trismus and soft tissue injury or infection. These local signs have been perceived widely as indicators for the evaluation of the analgesic value efficacy and wound healing of various physiotherapeutic means by many researchers, data, and articles [27-29].

Ozone $\left(\mathrm{O}_{3}\right)$ - in various forms being gaseous or dissolved in aqueous solutions, like water or extra virgin olive-oil formed gel - is used for topical therapeutic management and parenteral administration (I.M, I.V, autohemotherapy, vaginal, and rectal insufflation) to facilitate and deliver ozone to tissues [20, 30]. Kazancioglu et al. proved successful the usage of ozone gas via plasma probe extraorally to facilitate wound healing and reduce pain after impacted lower third molar surgery [4]. However, for our present research, the ozonized gel form was chosen because of some merits [31]. These can be highlighted by its simplicity of application intraorally, high concentration of ozone molecules, duration, and stability of the compound for long time more than gaseous form of ozone. There is no necessity of complex methods to produce and store ozonized olive-oil gel, self-administrated by the patient easily comparing with the ozone gas that needs professional help and administration; however, our patients exhibited no allergic or toxic complications.

Huth et al., reiterated that the biological characteristic and biocompatibility of aqueous ozone on oral epithelial and fibroblast cells were conserved best when matched to gaseous ozone [12]. The ozonides in the gel release active ozone in protracted time when it is in contact and cover the wound tissues at body temperature, which in turn affects positively soft tissue repair [32]. Pain threshold and intensity most probably vary amongst patients; for this reason per se, a split-mouth study was conducted to avoid bias during data collection. The surgical trauma occurred after surgical removal of impacted lower third molars, resulting in up-regulation of biochemical mediators of both pain and inflammation. These are exemplified by histamine, serotonin, bradykinin and prostaglandins [33]. The post-operative pain is mainly controlled via analgesics which are associated with undesirable systemic effects, such as gastrointestinal disturbance, bleeding, and allergic reactions [33]. According to VAS scores of post-operation, pain was sensed considerably less when ozonized gel was used topically. It can be ascribed to the anti-inflammatory effects of this ozonized gel leading to reduction of post-operative pain as well as the release of chemical mediators [34]. There is a proposed mechanism that reduces pain. This was studied by VelioBocci under the effect of analgesic action of ozone. Its mechanism is summarized by increasing and stimulating the secretion of vasodilators, like nitric oxide NO [35]. the topical effect of ozonides over the surface of surgical wounds might also be traced, leading to decreasing wound inflammation and covering exposed nerve ending; this leads to significant reduction in pain and the total analgesic doses taken ( $p=0.000 ; p>0.05)$. It clearly proves the analgesic effect of 
ozonized olive-oil gel.

Oral soft tissue healing is a dynamic and complicated process of restoring cellular structures and tissue layers [36] The healing oral epithelial tissue is also an complex process that uses the interactions between keratinocytes and the extracellular matrix - as a results of cells migration, proliferation, and differentiation - restoring the structure and function of this tissue $[3,12]$.

The topical layer of ozonized gel in the initial phase of surgery possibly prevents wound contamination and modulates the cellular and humoral immunity. Such a phase activates the macrophage and stimulates synthesis of biologically active substances [9]. Likewise, the biosynthetic and analgesic properties of ozone facilitate soft tissue healing by increasing the $\mathrm{PO}_{2}$ in tissues and activating the process of intercellular aerobic anti-hypoxic action. This eases transportation of oxygen by inhibiting RBCs aggregation [9]. In our study, the evaluation of soft tissue healing on 7 th day was based on the criteria given by Landry et al. and Gonshor [18, 19]. They revealed significant effect of ozonized gel on wound injury after surgical extraction of impacted lower mandibular molar $(\mathrm{p}=0.002 ; \mathrm{p}>0.05)$.

Filippiobserved that the aqueous form of ozone can accelerate the healing mechanism and rate in oral mucosa especially in the first two post-operative days [37]. However, ozonized water could not be used effectively due to its short half-life, which is 10 hours at room temperatures compared with ozonized olive-oil gel that is up to 3-4 weeks at room temperature [38]. In spite of this advantage of ozonized olive-oil gel, the anti-microbial effect is transient and needs to be reapplied topically to achieve good results according to Sivalingam et al.[39]. Thus, our patients were provided with ajar of ozonized gel as post-operative seven days dressing soft tissue injury, benefiting from the ability to penetrate hard and soft tissue [40]. A study by Guerra et al. suggested that ozone gel (Oleozon, Cuba) can be effective treatment for alveolitis better and faster in healing than Alvogyl and antibiotic therapy [41]. Nagayoshi et al. reiterated the antimicrobial efficacy of aqueous form of ozone used intraorally as a treatment of infection for exodontia, chronic soft tissue injury, after radiotherapy soft tissue effect, aphthae, advance periodontitis, mycosis and disinfection of root canal [42]. Related and purposeful sufficient evidence in a considerable number of studies underpinned the toxicity of ozone, especially the gaseous form inhalation leading to toxic effects. Such incidences are exemplified by upper respiratory irritation, headache, vomiting. They are managed by placing patients in supine position, taking vitamin $\mathrm{E}$, and using n-acetylcystiene [20].

Huth et al. verified that the aqueous form of ozone was less cytotoxic than gaseous ozone and antimicrobial, like chlorhexidine digluconate $2 \%, 0.2 \%$, sodium hypochlorite $\mathrm{NaOCl} 5.25 \%, 2.25 \%$, and hydrogen peroxide $\mathrm{H}_{2} \mathrm{O}_{2} 3 \%$. They proved the efficacy of aqueous form of ozone on soft tissue repairing and healing (43); however, our patients exhibited no toxicity or complications. Grossi et al. assessed the quality of life and post-operative discomfort after the third molar surgery; they indicated the positive effect of ozone therapy on quality of life according to OHIP-14 questionnaire [16].

\section{Conclusion}

Our study demonstrated that ozonized olive-oil gel is an effective method for reducing acute post-operative pain, enhancing and improving soft tissue repair and healing.

\section{Funding}

This study was funded by Damascus University, Syria.

\section{Ethical approval}

Accordance with the Declaration of Helsinki 1964 and its amendments and with the ethical standards of institutional and national research committee.

\section{Informed consent}

All individual participants in our study provided an informed written consent.

\section{Acknowledgment}

This research was funded by Damascus University.

\section{References}

[1]. Baysan A, Lynch E. The use of ozone in dentistry and medicine. Primary Dental Care. $2005 \operatorname{Apr}(2): 47-52$

[2]. Lynch E. Evidence-based caries reversal using ozone. J Esthet Restor Dent. 2008;20(4):218-22.Pubmed PMID: 18767993.

[3]. Seidler V, Linetskiy I, Hubálková H, Stanková H, Smucler R, Mazánek J. Ozone and its usage in general medicine and dentistry. A review article. Prague Med Rep. 2008;109(1):5-13.Pubmed PMID: 19097384.

[4]. Kazancioglu HO, Kurklu E, Ezirganli S. Effects of ozone therapy on pain, swelling, and trismus following third molar surgery. Int J Oral Maxillofac Surg. 2014 May;43(5):644-8.Pubmed PMID: 24332588.

[5]. Clavo B, Catalá L, Pérez JL, Rodríguez V, Robaina F. Ozone Therapy on Cerebral Blood Flow: A Preliminary Report. Evid Based Complement Alternat Med. 2004 Dec;1(3):315-319.Pubmed PMID: 15841265.

[6]. Stübinger S, Sader R, Filippi A. The use of ozone in dentistry and maxillofacial surgery: a review. Quintessence Int. 2006 May 1;37(5).

[7]. Oikarinen K. Postoperative pain after mandibular third-molar surgery. Acta Odontol. Scand. 1991 Jan 1;49(1):7-13.

[8]. López-Ramírez M, Vílchez-Pérez MA, Gargallo-Albiol J, ArnabatDomínguez J, Gay-Escoda C. Efficacy of low-level laser therapy in the management of pain, facial swelling, and postoperative trismus after a lower third molar extraction. A preliminary study. Lasers Med Sci. 2012 May;27(3):55966.Pubmed PMID: 21617973.

[9]. A SR, Reddy N, Dinapadu S, Reddy M, Pasari S. Role of ozone therapy in minimal intervention dentistry and endodontics - a review. J Int Oral Health. 2013 Jun;5(3):102-8.Pubmed PMID: 24155611.

[10]. Ishizaki K, Sawadaishi K, Miura K, Shinriki N. Effect of ozone on plasmid DNA of Escherichia coli in situ. Water Res. 1987 Jul 1;21(7):823-7.

[11]. Nagayoshi M, Fukuizumi T, Kitamura C, Yano J, Terashita M, Nishihara T. Efficacy of ozone on survival and permeability of oral microorganisms. Oral Microbiol Immunol. 2004 Aug;19(4):240-6. Pubmed PMID: 15209994.

[12]. Huth KC, Jakob FM, Saugel B, Cappello C, Paschos E, Hollweck R, et al. Effect of ozone on oral cells compared with established antimicrobials. Eur J Oral Sci. 2006 Oct;114(5):435-40.Pubmed PMID: 17026511.

[13]. Patel PV, Gujjari SK. The Morphometrical and Histopathological Changes which were Observed after Topical Ozone Therapy on an Exophytic Fibrous Gingival Lesion: A Case Report. J Clin Diagn Res. 2013 Jun;7(6):1239-43. Pubmed PMID: 23905150.

[14]. Baysan A, Lynch E. Clinical reversal of root caries using ozone: 6-month results. Am J Dent. 2007 Aug;20(4):203-8.Pubmed PMID: 17907479.

[15]. Slade GD, Foy SP, Shugars DA, Phillips C, White Jr RP. The impact of third molar symptoms, pain, and swelling on oral health-related quality of life. J Oral Maxillofac Surg. 2004 Sep 1;62(9):1118-24.

[16]. Grossi GB, Maiorana C, Garramone RA, Borgonovo A, Creminelli L, Santoro $\mathrm{F}$. Assessing postoperative discomfort after third molar surgery: a prospective study. J Oral Maxillofac Surg. 2007 May 1;65(5):901-17.=

[17]. Rathnam A, Madan N, Madan N. The language of pain: A short study. Con- 
temp Clin Dent. 2010 Jul;1(3):142-5.Pubmed PMID: 22114404

[18]. Gonshor A. Technique for producing platelet-rich plasma and platelet concentrate: background and process. Int J Periodontics Restorative Dent. 2002 Dec 1;22(6):547-58.

[19]. Landry RG. Effectiveness of benzydamine HC1 in the treatment of periodontal post-surgical patients (Doctoral dissertation, Faculty of Dentistry, University of Toronto). 1985.

[20]. Mohammadi Z, Shalavi S, Soltani MK, Asgary S. A review of the properties and applications of ozone in endodontics: an update. Iran Endod J. 2013 Spring;8(2):40-3.Pubmed PMID: 23717326.

[21]. Rothchild JA. Current Concepts of Oxygen Ozone Therapy for Dentistry in the United States.

[22]. Verrazzo G, Coppola L, Luongo C, Sammartino A, Giunta R, Grassia A, et al. Hyperbaric oxygen, oxygen-ozone therapy, and rheologic parameters of blood in patients with peripheral occlusive arterial disease. Undersea Hyperb Med. 1995 Mar;22(1):17-22.Pubmed PMID: 7742706.

[23]. Shiratori R, Kaneko Y, Kobayashi Y, Yamamoto Y, Sano H, Ishizu Y, et al. Can ozone administration activate the tissue metabolism?--A study on brain metabolism during hypoxic hypoxia. Masui. 1993 Jan;42(1):2-6.Pubmed PMID: 8433487.

[24]. Oosting RS, Van Rees-Verhoef M, Verhoef J, Van Golde LM, Van Bree L. Effects of ozone on cellular ATP levels in rat and mouse alveolar macrophages. Toxicology. 1991;70(2):195-202.Pubmed PMID: 1763414

[25]. Bocci V, Luzzi E, Corradeschi F, Silvestri S. Studies on the biological effects of ozone: 6. Production of transforming growth factor 1 by human blood after ozone treatment. J Biol Regul Homeost Agents. 1994 OctDec;8(4):108-12.Pubmed PMID: 7660851

[26]. Martínez-Sánchez G, Al-Dalain SM, Menéndez S, Re L, Giuliani A, Candelario-Jalil E, et al. Therapeutic efficacy of ozone in patients with diabetic foot. Eur J Pharmacol. 2005 Oct 31;523(1-3):151-61.Pubmed PMID: 16198334

[27]. Bamgbose BO, Akinwande JA, Adeyemo WL, Ladeinde AL, Arotiba GT, Ogunlewe MO. Effects of co-administered dexamethasone and diclofenac potassium on pain, swelling and trismus following third molar surgery. Head Face Med. 2005 Nov 7;1:11.Pubmed PMID: 16274480.

[28]. Markovic A, Todorovic Lj. Effectiveness of dexamethasone and low-power laser in minimizing oedema after third molar surgery: a clinical trial. Int J Oral Maxillofac Surg. 2007 Mar;36(3):226-9.Pubmed PMID: 17157479.

[29]. Forouzanfar T, Sabelis A, Ausems S, Baart JA, Van Der Waal I. Effect of ice compression on pain after mandibular third molar surgery: a singleblind, randomized controlled trial. Int. J. Oral Maxillofac. Surg. 2008 Sep 1;37(9):824-30.
[30]. Bocci VA. Scientific and medical aspects of ozone therapy. State of the art. Arch Med Res. 2006 May;37(4):425-35.Pubmed PMID: 16624639.

[31]. Gupta G, Mansi B. Ozone therapy in periodontics. J Med Life. 2012 Feb 22;5(1):59.

[32]. Patel PV, Kumar V, Kumar S, Gd V, Patel A. Therapeutic effect of topical ozonated oil on the epithelial healing of palatal wound sites: a planimetrical and cytological study. J Investig Clin Dent. 2011 Nov;2(4):248-58.Pubmed PMID: 25426896.

[33]. Kim K, Brar P, Jakubowski J, Kaltman S, Lopez E. The use of corticosteroids and nonsteroidal antiinflammatory medication for the management of pain and inflammation after third molar surgery: a review of the literature. Oral Surg Oral Med Oral Pathol Oral Radiol Endod. 2009 May;107(5):630-40. Pubmed PMID: 19157919.

[34]. Azuma K, Mori T, Kawamoto K, Kuroda K, Tsuka T, Imagawa T, et al. Antiinflammatory effects of ozonated water in an experimental mouse model. Biomed Rep. 2014 Sep;2(5):671-674.Pubmed PMID: 25054009.

[35]. 35. Bocci V. Ozone as Janus: this controversial gas can be either toxic or medically useful. Mediators Inflamm. 2004 Feb 11;13(1):3-11.

[36]. George Broughton II, Janis JE, Attinger CE. The basic science of wound healing. Plast. Reconstr. Surg. 2006 Jun 1;117(7S):12S-34S.

[37]. Filippi A. The influence of ozonised water on the epithelial wound healing process in the oral cavity. Clinic of Oral Surgery, Radiology and Oral Medicine, University of Basel, Switzerldand Available at: WWW OXYPLUS NET. 2001.

[38]. Saini R. Ozone therapy in dentistry: A strategic review. J Nat Sci Biol Med. 2011 Jul;2(2):151-3.Pubmed PMID: 22346227.

[39]. Sivalingam VP, Panneerselvam E, Raja KV, Gopi G. Does Topical Ozone Therapy Improve Patient Comfort After Surgical Removal of Impacted Mandibular Third Molar? A Randomized Controlled Trial. J Oral Maxillofac Surg. 2017 Jan;75(1):51.e1-e9.Pubmed PMID: 27741414.

[40]. Khullar S, Mittal A, Kumar M, Perwez E, Kumar A. Ozone Therapy In pediatric dentistry: An alternate approach.intJ. Dent. Sci.. 2012;10(2):1-7.

[41]. Cruz Guerra O, Menéndez Cepero S, Martínez Jordán ME, VÁZQUEZ C. Aplicación de la ozonoterapia en el tratamiento de la alveolitis. Revista Cubana de Estomatología. 1997;34(1):21-4.

[42]. Nagayoshi M, Kitamura C, Fukuizumi T, Nishihara T, Terashita M. Antimicrobial effect of ozonated water on bacteria invading dentinal tubules. J Endod. 2004 Nov;30(11):778-81.Pubmed PMID: 15505509.

[43]. Fotos PG, Koorbusch GF, Sarasin DS, Kist RJ. Evaluation of intra-alveolar chlorhexidine dressings after removal of impacted mandibular third molars. Oral Surg Oral Med Oral Pathol. 1992 Mar;73(3):383-8.Pubmed PMID: 1545974 . 